\title{
Cadmium and lead in compounded feeds
}

\author{
G. $\operatorname{Vos}^{1}$, J. J. M. H. Teeuwen ${ }^{1}$ and K. Vreman ${ }^{2}$ \\ ${ }^{1}$ State Institute for Quality Control of Agricultural Products (RIKILT), P.O. Box \\ 230, 6700 AE Wageningen, Netherlands \\ ${ }^{2}$ Institute for Livestock Feeding and Nutrition Research (IVVO), P.O. Box 160, \\ 8200 AD Lelystad, Netherlands
}

Received 14 January 1986; accepted 16 May 1986

Key words: compounded feeds, cadmium, lead

\begin{abstract}
Compounded feeds $(n=452)$ for dairy cattle, sows, piglets, growing pigs, layers and broilers were investigated for cadmium and lead. The average cadmium content varied between 0.126 and $0.174 \mathrm{mg} / \mathrm{kg}$. In $88 \%$ of the investigated samples a cadmium content of $<0.2 \mathrm{mg} / \mathrm{kg}$ was found. Only in two samples a cadmium level $>0.5 \mathrm{mg} / \mathrm{kg}$ was found. The average lead content varied from 0.82 to $1.70 \mathrm{mg} / \mathrm{kg}$. In only two samples the maximum permissible concentration of $5.0 \mathrm{mg} / \mathrm{kg}$ was exceeded.
\end{abstract}

\section{Introduction}

In the Netherlands, as in many other countries, much attention is paid to the presence of contaminants in the food chain. With respect to lead and especially cadmium it is believed to be necessary to reduce the input of these elements into the environment as much as possible. Since contaminants like lead and cadmium are introduced into the environment along various routes different measures must be taken to achieve this. With respect to agricultural activities the excrements of food-producing animals can be a significant route of environmental contamination. This route has become more important during the last decades due to the increased use of compounded feeds, which disturb the natural cycle of intake and secretion of minerals and trace elements on stock-farms. It is therefore considered important to limit the presence of potentially toxic elements in animal feeds.

Increasing dietary concentrations of cadmium and lead are also associated with increases in tissue cadmium and lead in both liver and kidney. For lead in compounded feeds a legal limit $(5.0 \mathrm{mg} / \mathrm{kg}$ product $)$ was fixed in the Netherlands several years ago. For cadmium a provisional guide value for the maximum permissible concentration of $0.5 \mathrm{mg} / \mathrm{kg}$ was introduced recently by the Ministry of Agriculture and Fisheries. An investigation was carried out in order to determine the present 
occurrence of cadmium and lead in compounded feeds. The results of this investigation are presented in this paper.

\section{Materials and methods}

Sampling was carried out by the General Inspection Service of the Ministry of Agriculture and Fisheries. The sampling strategy was partly based on the contribution of the individual feeds to the total production of compounded feeds in the Netherlands. Furthermore the number of investigated samples had to be sufficient to obtain a representative picture of the cadmium and lead levels in the individual compounded feeds. Compounded feeds for dairy cattle, sows, piglets, growing pigs, layers and broilers were sampled in 1982 and 1983. Additionally, a small number of samples of growing pig and broiler feed was taken in 1984.

Before analysis samples were grounded and homogenized. The samples were not dried. Sample digestions were carried out by a dry-ashing procedure. $1 \mathrm{~g}$ of sample was transferred to a quartz vessel. After the addition of $2.5 \mathrm{ml} 65 \%(\mathrm{~m} / \mathrm{m}) \mathrm{HNO}_{3}$ and $2.5 \mathrm{ml}$ of a $10 \%(\mathrm{~m} / \mathrm{v}) \mathrm{Mg}\left(\mathrm{NO}_{3}\right)_{2}$ solution the sample was evaporated to dryness on a hot plate.

Subsequently the vessel, covered with a quartz plate, was placed in a muffle furnace. The temperature was increased slowly $\left(50{ }^{\circ} \mathrm{C}\right.$ per hour $)$ to $450{ }^{\circ} \mathrm{C}$ and this final temperature was maintained for $8-9$ hours. After cooling, $1 \mathrm{ml}$ of $65 \%(\mathrm{~m} / \mathrm{m})$ $\mathrm{HNO}_{3}$ was added. After evaporation to dryness on a hot plate, the sample was placed in the muffle furnace $\left(450^{\circ} \mathrm{C}\right)$ for 30 minutes. If the remaining ash still contained black particles, this procedure was repeated until a white ash was obtained. Finally $0.5 \mathrm{ml}$ of $30 \%(\mathrm{~m} / \mathrm{m}) \mathrm{HCl}$ and $4.5 \mathrm{ml}$ of water were added and the ash was dissolved while stirring. Cadmium and lead were determined by differential pulse anodic stripping voltametry using a Metrohm polarographic analyzer and a Hanging Mercury Drop Electrode (HMDE). A sodium acetate/acetic acid buffer solution was used. Traces of lead and cadmium were removed from this solution by an electrochemical procedure. A deposition potential of $-0.8 \mathrm{~V}$ was applied. Only reagents of recognized analytical quality and double distilled water were used. The detection limit of the described analytical procedure was $0.005 \mathrm{mg} / \mathrm{kg}$ for cadmium and $0.05 \mathrm{mg} / \mathrm{kg}$ for lead. All analyses were carried out at least in duplicate, while within each batch of samples a blank was run also. For the analyses $(n=15)$ of NBS Citrus Leaves 1572 a cadmium and lead concentration of $0.058 \pm 0.024 \mathrm{mg} / \mathrm{kg}$ (certified value $0.03 \pm 0.01 \mathrm{mg} / \mathrm{kg}$ ) and $13.46 \pm 0.74 \mathrm{mg} / \mathrm{kg}$ (certified value $13.3 \pm 2.4$ $\mathrm{mg} / \mathrm{kg}$ ) were found respectively. For the addition of known quantities of cadmium and lead to several samples recoveries of $101 \pm 8 \%$ and $100 \pm 13 \%$ were obtained for cadmium and lead respectively $(n=42)$.

\section{Results and discussion}

The results for cadmium and lead are summarized in Tables 1 and 2 respectively. All data are given in $\mathrm{mg}$ per $\mathrm{kg}$ feed as such. The results for the different sampling periods were comparable and are therefore not reported separately. Since the cad- 
Table 1. Cadmium content (in $\mathrm{mg} / \mathrm{kg}$ product) of different compounded feeds

\begin{tabular}{llllllll}
\hline & \multicolumn{2}{l}{ Compounded feeds } & & & \\
\cline { 2 - 7 } & dairy cattle & growing pig & piglet & sow & layer & broiler \\
Number of samples & 100 & 121 & 30 & & 30 & 75 & 96 \\
Range & $0.036-0.252$ & $0.040-0.496$ & $0.064-0.347$ & $0.078-0.632$ & $0.056-0.331$ & $0.048-0.457$ \\
Samples $>0.5 \mathrm{mg} / \mathrm{kg}^{1}$ & 0 & 0 & 0 & 2 & 0 & 0 \\
Average \pm s.d. & $0.126 \pm 0.042$ & $0.127 \pm 0.076$ & $0.142 \pm 0.078$ & $0.174 \pm 0.135$ & $0.130 \pm 0.057$ & $0.154 \pm 0.086$ \\
Median & 0.114 & 0.108 & 0.136 & 0.130 & 0.116 & 0.142 \\
$90 \%$ value & 0.191 & 0.195 & 0.288 & 0.344 & 0.185 & 0.278
\end{tabular}

${ }^{1}$ Provisional guideline in the Netherlands.

Table 2. Lead content (in $\mathrm{mg} / \mathrm{kg}$ product) of different compounded feeds.

\begin{tabular}{lllllll}
\hline & \multicolumn{2}{l}{ Compounded feeds } & & & & \\
\cline { 2 - 7 } & dairy cattle & growing pig & piglet & sow & layer & broiler \\
Number of samples & 100 & 121 & 30 & 30 & 75 & 96 \\
Range & $0.64-4.64$ & $0.63-12.4$ & $0.44-1.81$ & $0.80-1.86$ & $0.46-42.3$ & $0.40-3.26$ \\
Samples $>5.0 \mathrm{mg} / \mathrm{kg}^{1}$ & 0 & 1 & 0 & 0 & 1 & 0 \\
Average $\pm \mathrm{s.d.}$ & $1.37 \pm 0.71$ & $1.13 \pm 1.11^{2}$ & $0.84 \pm 0.27$ & $1.11 \pm 0.26$ & $1.70 \pm 4.80^{3}$ & $0.83 \pm 0.35$ \\
Median & 1.41 & 0.95 & 0.86 & 1.04 & 1.02 & 0.79 \\
$90 \%$ value & 1.98 & 1.34 & 0.89 & 1.10 & 1.81 & 1.10 \\
\hline
\end{tabular}

${ }^{1}$ Legal limit in the Netherlands.

${ }^{2}$ Omitting the aberrant concentration of $12.4 \mathrm{mg} / \mathrm{kg}: 1.03 \pm 0.41 \mathrm{mg} / \mathrm{kg}$.

${ }^{3}$ Omitting the aberrant concentration of $42.3 \mathrm{mg} / \mathrm{kg}: 1.16 \pm 0.61 \mathrm{mg} / \mathrm{kg}$.

mium and lead levels generally did not show a normal distribution, median values and ranges are listed also.

High cadmium levels can occur in compounded feeds due to the use of cadmiumcontaining feed components. For most compounded feeds high phosphate mineral supplements are the main cadmium source. The cadmium levels found in the investigated feeds in the present study generally were low. The average cadmium content varied from 0.126 to $0.174 \mathrm{mg} / \mathrm{kg}$, while for about $88 \%$ of the investigated samples a cadmium content of $<0.2 \mathrm{mg} / \mathrm{kg}$ was found. The Dutch provisional guideline, i.e. $0.5 \mathrm{mg} / \mathrm{kg}$, was exceeded in two samples of sow feed only.

Literature data on the presence of cadmium and lead in compounded feeds are scarce. In Germany, Crössmann (Crössmann \& Egels, 1975; Crössmann, 1977/ 1978) extensively investigated the presence of cadmium, lead and mercury in compounded feeds and individual feed components. Taking into consideration that Crössmann reported his data based on dry matter and that the given average levels were calculated using only values above the detection limit $(0.01 \mathrm{mg} / \mathrm{kg})$, the German data are in reasonable agreement with the results of the present study. In general slightly higher cadmium levels were reported by Crössmann, especially for sow, layer and broiler feeds. 
Compared with the Dutch legal limit of $5.0 \mathrm{mg} / \mathrm{kg}$, the lead levels found in the different compounded feeds may be regarded as low also. The average lead content varied between 0.83 and $1.70 \mathrm{mg} / \mathrm{kg}$. In two samples the mentioned legal limit for lead in compounded feeds was exceeded. When a few samples are excluded the variation in the concentrations found was limited, which is illustrated by the relatively small difference between most median and $90 \%$ values. The lead levels found in the present study are in good agreement with the data reported by Crössmann (Crössmann \& Egels, 1975; Crössmann, 1977/1978).

\section{Acknowledgement}

The investigation discussed in the present paper was part of a project carried out within the framework of the 'Working Party on Minerals in Concentrated Feeds in relation to Manuring and Environment' of the National Council of Agricultural Research.

\section{References}

Crössmann, G. \& W. Egels, 1975. Untersuchungen auf Schwermetalle in Mischfuttermitteln. Kraftfutter 58: 266-269.

Crössmann, G., 1977/1978. Schwermetalle in handels- und wirtschaftseigenen Futtermitteln Berichte über Landwirtschaft 55: 785-795. 